\title{
Guest editorial: How technology is changing the design and delivery of services
}

\author{
Mark M. Davis • James C. Spohrer • Paul P. Maglio
}

Received: 4 January 2011 /Revised: 4 January 2011 / Accepted: 9 January 2011 / Published online: 3 February 2011

(C) Springer Science+Business Media, LLC 2011

At one time, the belief was that services-ranging from healthcare to retail, from banking to education-were the exclusive domain of local providers and were therefore impervious to foreign competition. Because they required direct interaction with customers, service providers needed to be located where their customers were (Bryson et al. 2004). This belief - along with many others associated with service activities requiring direct customer interactions - is no longer true because information technology has fundamentally changed the way many services are now designed and delivered (Karmarkar 2004).

In this editorial, we introduce a framework for service managers that shows how advances in technology are continuing to change the way service providers and their customers interact; how both providers and customers access resources and unlock their capabilities in the cocreation of value. We also identify some major challenges confronting today's service managers who are competing in a rapidly changing global knowledge economy. Their success in addressing these challenges requires increasingly sophisticated management techniques that continue to focus on creating value for both direct and indirect customerprovider interactions.

\section{Defining value}

Value can take many forms and mean different things to different customers (Spohrer and Maglio 2010; Vargo et al.

\footnotetext{
M. M. Davis $(\bowtie)$

Bentley University,

Waltham, MA, USA

e-mail: mdavis@bentley.edu

J. C. Spohrer · P. P. Maglio

IBM Research-Almaden,

San Jose, CA, USA
}

2008). Value can mean that it is less expensive, as for those customers who shop at Wal-Mart for its "everyday low prices" or fly RyanAir. Value can mean that it is more convenient, as when you buy books at Amazon, order groceries online at Peapod, or use the "FastPass" lane on the highway to pay a toll electronically. Value may also take the form of information, as when Amazon tells you what other books buyers who purchased the same book have also purchased, or when Expedia provides a list of different airlines going to a city and a comparison of their respective airfares. Value can also take the form of more personalized relationships and interactions, as when you check into a hotel and they know your personal preferences because you have stayed there before.

The key issue in creating value is to provide benefits (including access to resources and capabilities) that are perceived by the customer to be greater than the costs, which includes money, time, and effort, associated with obtaining these benefits. We divide perceived customer value into three broad categories: (a) low cost, (b) the experience, and (c) innovation (Zeithaml 1988).

Low cost The Internet is clearly a major factor in the power shift from providers to customers (Toffler 1990; Tapscott and Ticoll 2003). Customers can now compare prices without ever leaving their homes or offices-popular web services compare prices of goods (such as www.Shopzilla. com and www.PriceGrabber.com), and services (such as www.Expedia.com and www.Orbitz.com); some web services even compare the price comparison websites (such as www.kayak.com and www.sidestep.com).

This ease of price comparison and subsequent purchase has increased the intensity of competition, putting more and more pressure on profits. Because price is the primary factor for many web-based purchases, customers who shop on the Internet most often perceive the benefits of the goods 
and services they buy as being almost the same among the providers. In other words, these goods and services are viewed as commodities; Internet customers, therefore, tend to maximize value by minimizing costs.

The experience Firms competing on this dimension focus their efforts on enhancing the service delivery process to distinguish themselves from competitors (Pine and Gilmore 1998). With the goal of gaining a competitive advantage with the experience they provide, these firms tend to interact face-to-face with their customers. Restaurants (e. g., three-star Michelin restaurants and chains such as Bugaboo Creek Steakhouse), hotels (the Ritz-Carlton and Four Seasons), airlines (Singapore Airlines), and retail operations (Nordstrom) provide excellent examples of firms that compete on the offered experience. Zappos, an online retailer that sells shoes, also focuses on providing customers with a "WOW Experience" (Hsieh 2010).

Enhancing the customer experience during the service delivery process requires additional investment in facilities and employee training, so these firms are usually not the low cost providers in their industries. The challenge for firms competing in this segment of the market is to ensure a reasonable profit while providing service delivery enhancements that justify higher prices so that their customers still perceive value.

Innovation There will always be customers who want the newest goods and services and who are willing to pay a premium for being the first to have them. With the life cycle for both goods and services becoming shorter and shorter, many firms are turning to innovation as a source of competitive advantage (Hagel and Singer 2000). Apple and Google are good examples of firms in this category with their seemingly continuous introduction of new goods and services. The major challenge for firms competing on this dimension is developing an innovative culture within their organizations so that a constant stream of new services are being developed and introduced into the marketplace (Sanford 2006; Moore 2006).

\section{Emerging trends}

We see several trends in how information technology is influencing the ways service providers interact with customers.

Increase in self service The growing trend in self service can be primarily attributed to service organizations trying to reduce operating costs (Meuter et al. 2000). By shifting more of the service process activities to their customers, firms are taking advantage of free labor. Examples here include self-cleaning of tables in fast food restaurants, selfservice check-in kiosks at airports and online airline checkin, self-service gas pumps, and self-service checkout lanes at supermarkets and retail stores. Additional reasons for the continued growth in self service include: (a) the customer's perception that it is faster and (b) the customer's desire to be more in control.

In most cases, firms offering these self-service options must recognize the need to continue to provide the traditional service so as not to alienate some customer segments; some people are just uncomfortable using selfservice technology, others simply continue to prefer the more traditional method (Campbell et al. forthcoming).

Increase in automation Automation often overlaps with self service in front-office services, but automation is also increasing in back-office services (Zysman 2006). For example, back-office automated switching used by telecommunication companies means that customers now function as telephone operators - dialing their own calls is a kind of front-office self service. For back-end automation, some companies are using natural language software to intercept and directly respond to email interactions with customers. Automation can impact physical, information, social, or combined processes when technology substitutes for functions previously performed by human beings, either as the service provider's employees or the customers themselves. For example, FastPass eliminates the exchange of money (physical), making change (information) and human-to-human contact (social) in speeding people and their vehicles through toll stations on bridges and highways. Inventory control systems for retail operations, cameras that recognize license plates for traffic congestion management systems and even food conveyor belts in sushi restaurants, all reflect the growing use of automation in service delivery systems.

Increase in globalization The ability to provide many service activities from anywhere in the world now allows companies to locate some services, such as customer support call centers, in regions with the lowest cost (Friedman 2005). Low labor costs are one reason for the significant growth in call centers in India, Panama and Morocco.

The Internet also facilitates international collaboration among service providers. For example, textbook publishers have materials edited in the Philippines, accounting firms have audit reports prepared in India, and movie makers have animations created in Korea and China. Some 
hospitals, like the Massachusetts General Hospital in Boston, send patient $\mathrm{x}$-rays through the Internet to India to be read by Indian doctors.

When labor costs are extremely low, customers may choose to travel to the service provider. For example, world-class hospitals in Asia now perform elective surgical procedures at a fraction of the cost (including travel) of having these procedures done in the United States (Oberholzer-Gee et al. 2007).

Increase in choice In 1994 there were approximately 500,000 consumer goods in total available in the United States. Today there are more than 24 million books available on Amazon, 15 million singles listed on Match. com and 100,000 DVDs available on Netflix. Similarly, in 1949 the average supermarket stocked 3,750 different items; today that number is more than 45,000 (Iyengar 2010). The trend of providing more choices to customers can be attributed in large part to two major developments:

(a) The centralization of physical inventories allows online companies, such as Amazon and Netflix, to economically offer a greater variety of products compared to traditional brick-and-mortar services that must maintain inventories at each of their retail locations. The continued emphasis on centralizing physical inventories extends beyond national borders to include the global distribution of goods through regional distribution centers. For example, using technology, the Toyota Distribution Center in Mansfield, MA, which is responsible for supporting 112 Toyota dealerships in New England and upstate New York, has virtual access to inventories of the other Toyota Distribution Centers when a specific part is ordered by a dealer that it does not have in stock.

(b) The digitization of goods and services virtually eliminates the holding costs typically associated with physical inventories, thereby allowing firms to expand their offerings almost without limit. And digitization provides opportunities for service providers to facilitate customer searches (Anderson 2006).

Both (a) and (b) are examples of how firms, with the proper technology, can now address small levels of demand for a large number of hard-to-find items, rather than only selling large volumes of a smaller number of popular items.

But sometimes, the significant increase in choice frustrates customers to the point where they do not make a decision (Iyengar and Lepper 2000). To help customers with the large number of choices now available as well as to assist providers in forecasting what customers want, recommendation engines identify additional related purchase options, based on the buying patterns of hundreds or thousands of other customers (Hennig-Thurau et al. 2010; Ostrom et al.
2010). Recommendation engines also increase basket size and revenues. The preference models that underlie recommendation engines can also be used by providers in designing new services to complement existing offerings.

The increase in choice also extends to include the growing number of channels through which businesses can provide service. For example, in addition to face-to-face customer interactions, there can be customer interactions on the telephone and online with the Internet. The emergence of these multiple channel offerings requires firms to take a systems approach that integrates all channels to ensure that a consistent and seamless service is provided to the customer (Neslin et al. 2006).

Increase in information As transmission, processing, and storage of data become both faster and more economical, the role of information in the delivery of service will continue to increase (Palmisano 2008). Some firms will collect customer data to better meet customer needs. Others will analyze customer data, particularly behavior data, which will allow them to adjust service offerings to better satisfy customers and to increase profits. Progressive Insurance, for example, collects large amounts of data on automobile driver behavior, which allows it to divide the automobile insurance market into smaller segments and thus better align driver risks with insurance premiums. Harrah's meticulously analyzes customer behavior in its casinos, which allows it to more accurately measure how new promotions increase revenues (Davenport and Harris 2007). And as noted earlier, Amazon uses data on customer buying patterns to offer suggestions for future book purchases, while online travel agencies like Expedia provide comparative pricing information as well as on-time flight arrival percentages.

We are truly in the information age. As more data become available and new techniques for analyzing the data are developed, firms continue to use information to gain a competitive advantage. The only caution here is having too much data - to the point where it encumbers the firm's ability to make timely decisions (also, known as "analysis paralysis") and leads overwhelmed customers to go to less confusing alternatives (Iyengar and Lepper 2000).

Focus on providing access as a competitive advantage As service core offerings tend towards commoditization, many firms now view providing access to the core service as a competitive advantage (Berry et al. 2006). Today, access to a firm's core service offering can include both physical and virtual access, such as Internet access to conduct financial transactions (replacing the need to visit the local branch bank), Virgin Atlantic's limousine service for business class customers, and Zoot's Cleaners that pick up and deliver your dry cleaning. OpenTable, an online reservation system for restaurants, is a good example of how technology can 
be used to provide access for those services that require face-to-face interactions with their customers.

Increasing power of the customer The power in the marketplace has clearly shifted from providers to customers (Grossman 2006). Because of technology, customers are no longer limited to relatively small numbers of local or even national service providers; the Internet now connects customers to literally the four corners of the world.

In addition, customers can now evaluate services and these ratings are available for potential customers. Expedia, for example rates hotels on a scale of $1-5$, while OpenTable similarly asks customers to rate restaurants. Customers looking for contractors to do home repairs can see their performance ratings from previous customers on Angie's List or ServiceMaster. EBay likewise provides customer satisfaction ratings for its sellers. Knowing that how they treat customers is now public information places increased pressure on providers to ensure that every customer is satisfied.

The growth in social networks, including Youtube, Twitter and Facebook, has also increased the power of the customer. Dissatisfied customers can now literally tell the world about their dissatisfaction. For example, the Sons of Maxwell band was unsatisfied with United Airlines after the guitar owned by lead singer Dave Carroll was broken during the flight. He subsequently wrote a song about it ("United Breaks Guitars"). The day the song came out on Youtube, United Airlines stock dropped $10 \%$ costing its shareholders more than $\$ 180$ million (and which would have bought more than 51,000 replacement guitars). (Ayers 2009). To demonstrate the power of social media networks, that song has been viewed on Youtube more than nine million times.

Perhaps more fundamentally, access to services through electronic means, coupled with social networking not only eliminates distribution costs-you can download software and access services through the Internet with almost no cost to the provider - but also turn the cost of distribution into a knowledge asset: the more people use services such as Facebook, Youtube, and Twitter, the more valuable it is to both providers and customers.

\section{Managerial challenges}

As we enter the early part of the 21 st century, we see significant changes occurring in the ways services are designed and delivered. The primary reason for these changes is technology. Technology is why there has been an increase in availability (24/7) and a decrease in the importance of location. Likewise, technology is the underlying reason for the shift from traditional synchronous communication in which interactions between provider and customer take place at the same time (such as with face-toface interactions and person-to-person telephone calls) to IT-based asynchronous communication in which interactions occur in a mediated way at different times (such as email and the Internet). Moreover, there is also a reverse trend towards more IT-based synchronous communication, such as teleconferencing and video conferencing.

At the same time, technology in and of itself will not create world class service organizations. Recruiting, training and retaining educated employees are also prerequisites for success.

We therefore see several challenges facing today's service managers including:

- Developing new ways of using information to add value for customers by understanding how the Internet and other technologies influence the service delivery process.

- Managing services in an increasingly competitive global environment where customer expectations and perceptions can vary significantly from country to country, and no country or region, regardless of its size, is immune to foreign service competition.

- Working in a fast-paced and constantly changing business environment, caused in large part by the continuous introduction of the latest state-of-the-art technologies.

- Managing a workforce where entirely new types of jobs are being created that will require better educated employees.

- Recruiting and training individuals from an increasingly diverse population. Technology will also continue to encourage remote workforces (for example, telecommuting) that will require new management skills.

- Lowering of wages in the developed world until they stabilize to a world-wide level.

- Providing higher levels of service to increasingly demanding customers in an ever-increasing competitive environment that requires maintaining or even reducing prices.

- Establishing consistently high levels of service quality across multiple channels.

- Unlocking customer capabilities so that they can play a greater role in the co-creation of value.

\section{Looking ahead}

Though service now constitutes the largest segment of the economies of every industrialized nation, and is significantly increasing in every country, the word "service" still gets a bad rap. It is often associated with low paying service jobs, such as those in retail operations, hotels, restaurants, and retail banking. And customer service usually has a negative connotation that is primarily associated with postsales services that address customer complaints.

But the service landscape is quickly changing, resulting in large part from innovations in technology. Many of the 
best jobs available in the coming years will be in services, but will be for knowledge workers (Johnson et al. 2005). Technology will continue to facilitate the redesign of existing service processes and the design of new service processes that ultimately will eliminate many tedious, repetitive, low-paying jobs, replacing them with higher paying knowledge workers (although probably not on a one-for-one basis). When done right, this will create a winwin-win situation in which the customer receives faster service that is less expensive, the provider significantly reduces operating costs, and the employees have higher paying and more interesting jobs.

Technology will also continue to raise the bar for service quality standards along with customer expectations. The judicious application of information technology will significantly reduce - even eliminate - errors because of improved information sharing and data mining internal to companies. Equally valuable will be improved informationsharing between customers and firms, enabling early identification of problems/errors, thereby leading to faster resolutions. Over time, customers will expect quality to improve continuously in service processes, just as they now expect continuous improvement in goods production.

In the end, it is clear that technology is changing the very nature of service. Smart firms will embrace this change and adapt. Increased customer involvement, increased automation, increased customer choice, increased information, and increased access are just some of the ways firms can increase the opportunity for value co-creation. But firms must be mindful of the many challenges these changes bring, perhaps the most important of which involve new ways of working and interacting among firms, employees, and customers, which in turn involve new distributions of knowledge and capabilities among the various stakeholders (Chesbrough 2011).

Those service firms that will survive and prosper will encourage change, welcome new technologies, and willingly engage both customers and employees in designing and delivering new services. Clearly, technology must play an integral role in every service organization's strategy. But equally important (if not more important) for service managers to acknowledge is the need for a highly educated workforce that is necessary to properly execute that strategy. Whether the service is high tech or high touch, self service or super service, information intense or interaction focused, traditional brick and mortar or Internet based, both technology and an educated workforce will continue to be prerequisites for success.

\section{References}

Anderson C (2006) The long tail. Hyperion, New York

Ayers C (2009) Revenge is best served cold — on YouTube: how a broken guitar became a smash hit. The Times (UK) July 22.
Berry LL, Shankar V, Parish JT, Cadwallader S, Dotzel T (2006) Creating new markets through service innovation. Sloan Manage Rev 47(2):56-63

Bryson JR, Daniels PW, Warf B (2004) Service worlds: people, organisations, technology. Routledge, London

Campbell CS, Maglio PP, Davis MM (forthcoming) From self-service to super-service: how to shift the boundary between customer and provider. Information Systems and eBusiness Management.

Chesbrough H (2011) Open service innovation: rethinking your business to grow and compete in a new era. Josey-Bass: Wiley, San Francisco

Davenport TH, Harris JG (2007) Competing on analytics: the new science of winning. Harvard Business School Press, Boston

Friedman T (2005) The world is flat: a brief history of the twenty-first century. Farrar, Straus and Giroux, New York

Grossman L (2006) Time's person of the year: you. Time Magazine. December 13

Hagel J, Singer M (2000) Unbundling the corporation. McKinsey Q 3:148-161

Hennig-Thurau T, Malthouse EC, Friege C, Gensler S, Lobschat L, Rangaswamy A, Skiera B (2010) The impact of new media on customer relationships. J Serv Res 13(3):311-330

Hsieh T (2010) Delivering happiness: a path to profits, passion, and purpose. Business Plus, New York

Iyengar SS (2010) The art of choosing. Twelve, New York

Iyengar SS, Lepper MR (2000) When choice is demotivating: can one desire too much of a good thing? J Pers Soc Psychol 79(6):995-1006

Johnson BC, Manyika JM, Yee LA (2005) The next revolution in interactions. McKinsey Q 4:20-33

Karmarkar U (2004) Will you survive the services revolution? Harv Bus Rev 82:100-108

Meuter ML, Ostrom AL, Roundtree RI, Bitner MJ (2000) Self-service technologies: understanding customer satisfaction with technology-based service encounters. J Mark 64:50-64

Moore GA (2006) Dealing with Darwin. Penguin, New York

Neslin SA, Grewal D, Leghorn R, Shankar V, Teerling ML, Thomas JS, Verhoef PC (2006) Challenges and opportunities in multichannel customer management. J Serv Res 9:95-112

Oberholzer-Gee F, Khanna T, Knoop CI (2007) Apollo hospitalsfirst-world healthcare at emerging-market prices. Harvard Business School Case 9-706-440.

Ostrom AL, Bitner MJ, Brown SW, Burkhard KA, Goul M, SmithDaniels V, Demirkan H, Rabinovich E (2010) Moving forward and making a difference: research priorities for the science of service. J Serv Res 13(1):4-36

Palmisano, SJ (2008) A smarter planet: the next leadership agenda. Council on Foreign Relations, November 6. URL: http://www. cfr.org/publication/17696/smarter_planet.html

Pine BJ III, Gilmore JH (1998) Welcome to the experience economy. Harv Bus Rev 76(4):97-105

Sanford LS (2006) Let go to grow: escaping the commodity trap. Prentice Hall, New York

Spohrer, JC, Maglio PP (2010) Toward a science of service systems: value and symbols. Handbook of Service Science, Editors Maglio, Kieliszewski, Spohrer, Spring, New York, NY. 157-195.

Tapscott D, Ticoll D (2003) The naked corporation: how the age of transparency will revolutionize business. Free Press, New York

Toffler A (1990) Powershift: knowledge, wealth and violence at the edge of 21st century. Bantam Books, New York

Vargo SL, Maglio PP, Akaka MA (2008) On value and value cocreation: a service systems and service logic perspective. Eur Manage J 26(3):145-152

Zeithaml VA (1988) Consumer perceptions of price, quality, and value: a means-end model and synthesis of evidence. J Mark 52:2-22

Zysman J (2006) The 4th service transformation: the algorithmic revolution. Communications of the ACM, 49(7) 